\title{
Future and Sustainability: Insects in Human Food
}

\section{Renaly Kaline Gomes dos Santos ${ }^{1}$, Rogério Silva de Almeida ${ }^{1}$, Danilo Salustiano dos Santos ${ }^{1}$, Fidelis Franco Felizardo da Silva ${ }^{1}$, José Narciso Francisco da Silva Filho ${ }^{1}$, Juliana Gonçalvez Gomes ${ }^{1}$, Geiza Michelle Angelo Pacheco ${ }^{1}$, Natália Costa da Silva ${ }^{2}$, Samarone Xavier da Silva ${ }^{3}$, Anderson Ferreira Vilela ${ }^{4 *}$, Arianne Dantas Viana ${ }^{4}$, Edilma Pinto Coutinho $^{5}$}

${ }^{1}$ Student Agroindustry Federal University of Paraíba - UFPB, Brazil

${ }^{2}$ Master's Student in Food Science at the State University of Campinas - UNICAMP, Brazil

${ }^{3}$ Master's Student in Food Technology at the State University of Campinas - UNICAMP,

Brazil

${ }^{4}$ Professor of the Agroindustry Course Federal University of Paraíba - UFPB, Brazil

${ }^{5}$ Professor at the Department of Rural Technology at the Federal Rural University of

Pernambuco - UFRPE, Brazil

*Corresponding Author: Anderson Ferreira Vilela, Professor of the Agroindustry Course

Federal University of Paraíba -UFPB, Brazil. E-mail: prof.ufpb.anderson@gmail.com
Received: November 22, 2021

Published: January 25, 2022

(c) All rights are reserved by Anderson

Ferreira Vilela., et al.

\begin{abstract}
Studies indicate that in the coming years the number of inhabitants on earth reaches at least 9.8 billion, thus an increase in the demand for food due to population growth. Because of this perspective, researchers are looking for new food alternatives. The present work aimed to deal with the bibliographic survey about the knowledge of entomofagia, nutritional and environmental advantages and difficulties of its insertion in the global culture. Entomophagy or anthropoentomophagy is defined as the consumption of insects or products containing them in its formulation, this practice is currently both well accepted and rejected, depending on the region of the planet and it has been growing due to the dissemination of knowledge that edible insects are rich in nutrients such as proteins, fats, vitamins and minerals, in addition to having sustainable production with low environmental impact. Through this study it can be observed that insects have characteristics of great relevance for the food area, since it contains a high nutritional value present in satisfactory amounts. Another positive point observed, is its low production cost when compared to other animals and its high rate of conversion feed which make them allies of the environment. However, the consumption of these insects faces some obstacles that need to be better studied, such as the resistance of the consumption of the population for cultural issues and also the scarcity of current legislation.
\end{abstract}

Keywords: Food Alternative; Entomophagy; Neophobia; Food Security

\section{Introduction}

According to a report by the United Nations - UN (2019), the planet reached about 7.8 billion inhabitants in 2019 and it is estimated that by 2050 this number reaches at least 9.8 billion inhabitants, $29 \%$ more than the current number, thus generating the need for more food to meet this demand. Another important factor is the changes in the distribution of income that directly affects the composition of demand for food [1,2]. Thus, we will have changes not only in the amount of food required, but also in the type of food and its contribution related to the population diet [3].

In high-income countries, annual meat consumption can reach $130 \mathrm{~kg}$ per person, and an increase of up to 50\% [4] is still expected. Since the demand for protein-rich foods is related to meat consumption, there will also be an increase in the demand for grains used in livestock feed - about $48 \%$ in high-income countries and up to $158 \%$ in China [2]. 
Thus, the demand for alternative sources of proteins is inevitable, since it would be necessary to increase conventional meat production by $70 \%$ to feed this population. However, with the current techniques used in livestock, it is impossible to grow production in a sustainable way [5].

Insects have a high nutritional content, a low cost for their production, and for these reasons, entomofagia is a great option for solving current problems and future problems predicted by the United Nations (UN). According to the Food and Agriculture Organization of the United Nations (FAO), the number of malnourished people in the world in 2016 was 804 million, a number that has even been growing in recent years [6].

The adoption of insects as a food source is generally based on three reasons: nutritional aspect, environmental factors and socioeconomic benefits. Insects provide a good source of proteins, minerals, vitamins and energy, with a lower cost of production when compared to traditional animal sources and may present good applicability in rural communities with less infrastructure, due to requiring less water and energy and not lacking large areas of cultivation [7].

Entomophagy, as its name suggests, is a habit of consuming insects or derived products, a practice that covers cultural issues and is part of the history of human evolution for centuries, in some regions of the world, especially in Asia, Latin America and Africa [8]. Insects suitable for human consumption are rich in proteins, vitamins, minerals and lipids of high quality, their proteins have greater ease of absorption by the body and can be better used when compared to other protein sources [9].

This study gathered information of a scientific nature in the form of literature review and was a result of a research group of students and teachers who, because of the difficulties of laboratory research caused by the Covid-19 pandemic, dedicated scholars and volunteers to the study of the potential use of insects in food production.

\section{Entomophagy}

Entomophagy is the use of insects and their derivatives as food [10]. Approximately 2 billion people in the world are consumers of insect-based products, however, this number has been growing with the increase in the commercialization and production of processed products, which often promote sensory improvements and consequent greater acceptance [11]. The United Nations recommends entomofagia as a possible solution to the limited supply of food in the world [12].
The main insect-eating peoples are found in countries located in tropical and subtropical regions, such as China, Mexico and Japan, since the biodiversity of these regions translates into a fauna of greater richness than that observed in countries located in temperate zones [7].

In Brazil, the culture of eating insects originates in indigenous peoples. Currently, the consumption of saúva (Atta sp.) in the north and northeast of the country is quite common, as is the larva of the coconut worm (Pachymerus nucleorum) in several regions and the carmine cochineal (Dactylopiuscoccus), from which itis used in the food industry, this is extracted a natural red pigment to color food [13].

The most consumed groups of insects are beetles (coleopterans) (31\%), butterflies (lepidopterans) (18\%) and bees, 18 wasps and ants (hymenepters) (14\%), followed by locusts and crickets (orthoptera) (13\%), cicadas, cochineals and bedbugs [14].

Recently, it is already possible to see the creation of insects on a larger scale and in places specifically equipped for this activity, where they are produced for both human and animal feeding. A practice that has become widespread and profitable in several regions of the world [15].

Despite the great historical references of the use of insects for human consumption, the insects lost space in the diet of most communities around the world and began to be seen with a negative aspect where the practice of insect consumption was related to primitive habits, soon after they were associated with pests, diseases, dirt, disgust and disdain [16].

The issue has come to the fore from the report released in 2013 by the Food and Agriculture Organization of the United Nations (FAO) that presented the benefits of insect consumption and its likely need on a global scale in 2050 to ensure food security in the world. From there, FAO, allied to other countries, works on research and knowledge sharing about entomofagia, with the objective of broadening the perception of nutritional, environmental value and the economic potential of insect breeding and consumption [10].

\section{Environmental aspects}

Insects have a high feed conversion rate, for example, crickets need six times less feed than livestock, four times less than sheep and twice as low as pigs and chickens to produce the same amount of protein. In addition, they emit fewer greenhouse gases and ammonia than conventional cattle. Therefore, insects are a potential source for conventional protein production, whether for direct hu- 
man consumption or indirectly in recomposed foods (with protein extracted from insects); and as a source of protein in mixtures of raw material [10].

As a comparison effect, for the production of $1 \mathrm{~kg}$ of protein, an insect breeding requires $18 \mathrm{~m} 2$ of area, $23000 \mathrm{~L}$ of water and $1 \mathrm{~g}$ of greenhouse gas is released for the animal to gain $1 \mathrm{~kg}$ of mass; while in a cattle ranch, it is required $198 \mathrm{~m} 2$ of area, $112000 \mathrm{~L}$ of water, and $2850 \mathrm{~g}$ of greenhouse gas are released into the atmosphere [17]. Below we will see some comparisons of insect production in relation to the production of commonly consumed proteins (Figures 1-4).

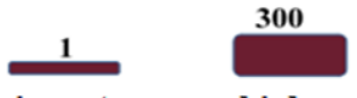

insect chicken

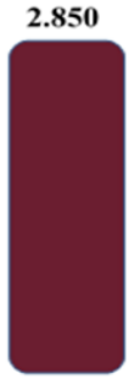

cow
Figure 1: Comparative global warming: Greenhouse gas released, in grams, so that the animal gains $1 \mathrm{~kg}$ of mass.

Source: Insects as food and feed, a new emerging agricultural sector: A review [18].
18

insect

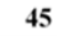

45

chicken

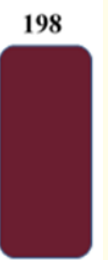

cow
Figure 2: Comparative land use: Area required, in square meters, for production of $1 \mathrm{~kg}$ of animal protein.

Source: Edible Insects [17].
10

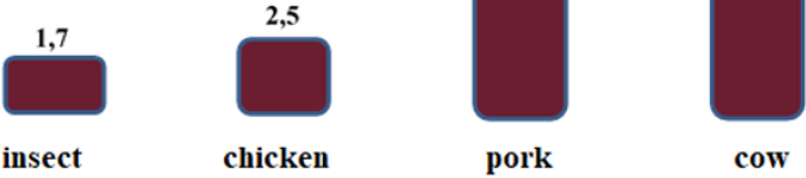

Figure 3: Comparative feed conversion: amount of food, in kilos, for gain of $1 \mathrm{~kg}$ of body mass.

Source: Insects as food and feed, a new emerging agricultural sector: a review [18].
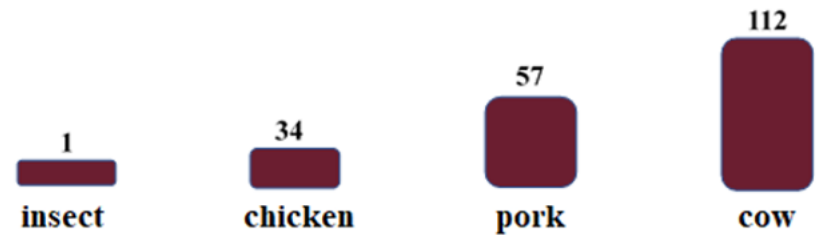

Figure 4: Comparative water expenditure: volume required, in liters, to produce $1 \mathrm{Kg}$ of protein.

Source: Edible Insects [17].

Another factor considered sustainable is the condition of being bioconverters, since they can feed on organic residues, such as food scraps, composting and animal manure, being thus used for the consumption of animals. Thus, insects convert a material that could be a polluting agent into a high-quality food resource, including for use in animal feed [19]. The creation and consumption of insects significantly reduces the presence of pesticides and their residues in food and the environment [12].

Insect species such as the black welded fly (Illucens hermetica), the 21 common fly (Musca domestica) and the larva of the flour ( Tenebrio molitor) are very efficient in bioconverting organic waste. For this reason, these species have been receiving attention, since they could collectively convert $1,300,000,000$ tons of bio waste per year $[20,21]$. 
With the increase of the population, the need for food to supply it becomes increasing, which can cause serious problems to the environment, resulting from the possible scarcity of natural resources available to agricultural activity [22].

\section{Nutritional aspects}

Insects are known to be, in most cases, an easy source of access to proteins, fats, vitamins and minerals such as: calcium, iron, zinc. They have a balanced nutritional profile that meets the human demands of amino acids, besides providing a high content of monounsaturated and polyunsaturated fatty acids [7].

Edible insects contain high quality proteins, vitamins and amino acids for humans [10]. The nutritional value of edible insects is one of the most relevant advantages of entomofagia, because they have high content of proteins, polyunsaturated fats, vitamins, fibers and minerals [16]. Due to the large number of existing insect species, their centesimal composition may vary according to the animal's evolutionary stage, sex, diet and environment, in addition to the preparation and processing carried out before consumption $[16,23]$.

In addition to being present in large quantity, proteins are recognized as high quality, as they have high concentrations of essential amino acids ranging from 46 to $96 \%$, associated with high rates of protein digestibility and absorption ranging from 76 to $96 \%$ [2426]. The fat content in edible insects ranges from 13 to $33 \%$ in Orthoptera, for example, crickets and locusts and Coleoptera, such as beetles and larvae. Insects tend to have a higher fat content in their larval form due to the higher energy requirements during their development [27]. Below, we have a comparison of proteins between insects and conventional animals (Figure 5).

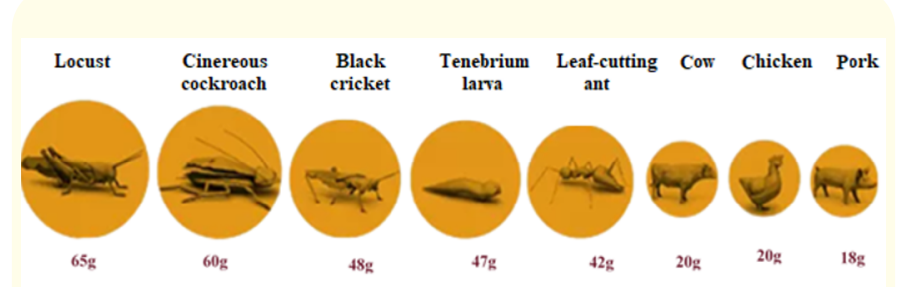

Figure 5: Comparative: grams of protein swum of protein sands per 100 grams of insects and other animals.

Source: The use of edible insects as an alternative source for human food [28].
According to studies conducted on the potential of edible insects in the food industry, table 1 shows the nutritional composition of some insect species that have consumption potential in the West. It can be seen that the species $A$. domesticus has a greater amount of protein, on the other hand the species $Z$. morio leads the fat percentage. It can be concluded in the same table that insects are alternative and viable sources of protein and lipids [29].

\begin{tabular}{|l|c|c|c|c|}
\hline Species & Protein (\%) & Fat (\%) & Gray (\%) & $\begin{array}{c}\text { Fiber } \\
\text { (\%) }\end{array}$ \\
\hline A. domesticus & 66,6 & 22,1 & 3,6 & 10,4 \\
\hline B. mills (pupa) & 52,6 & 29,4 & 6,9 & 6,6 \\
\hline T. molitor & 50,9 & 36,1 & 3,8 & 4,2 \\
\hline Z. morio & 54,3 & 40,3 & 3,6 & 3,6 \\
\hline G. assimilis & 59.2 & 34.3 & 4.2 & 3.2 \\
\hline L. migratory & 62,2 & 6,4 & 6,4 & 8,3 \\
\hline
\end{tabular}

Table 1: Nutritional composition of insects.

Source: Study of the potential of edible insects for application in the food industry [27].

Insects are also excellent sources of minerals such as manganese, copper, selenium, phosphory, magnesium, iron, zinc and calcium, where the consumption of $100 \mathrm{~g}$ of matter guarantees the recommended daily requirements of these elements for humans [29].

\section{Difficulties of insect consumption}

Most of the consumer market claims not to like the idea of using insects as a food source, this attitude is passed on from generation to generation to the point that children associate the ingestion of insects with something unpleasant. The main reason for the refusal of insects is to be tied to the idea that they are "dirty" and "unclean" [30].

Much of this rejection of consuming insects is linked to the unhealthy conditions of the places they inhabit and thus being able to transmit diseases to humans. The fact that some insects are dirty has nothing to do with them, in fact they only inhabit sewers and other places of low hygiene on beside the humans who created these places, since before, these animals lived in clean and healthy habitats [31]. Insects are dirty because they are in dirty environments, just as pigs are dirty if raised in dumps, but can be cleaned and produce a quality and safe pork for consumption [32]. 
The genus is also a factor that contributes to the rejection of insects as an ingredient of a dish. Women, at least in Western culture, are educated to feel disgust, while men are reinforced a behavior that tends to evidence their virility and masculinity before society. As women, predominantly, have control of food consumption, they end up rejecting insects more firmly in response to their feeling of disgust to which they were educated [33].

The consumer's attitude towards entomofagia results from a series of psychological, social, religious and anthropological factors. The depth of this aspect, long rooted, reflects in a strong resistance to entomofagia, which will require time and investment to be accepted hegemonicly. Dietary preferences are formed in childhood, and fixed over time, thus, the older the consumer is, the greater their resistance to changes in the dietary pattern [7].

There are some limiting factors in relation to the implementation of entomophagy, one of them is the absence of legislation that regulates this practice in most countries, especially in western countries [17]. Currently, there are concentrated efforts among FAO, scholars and investors in the area to combat the current legislative barriers that hinder the development of the commercial insect industry [18].

As examples of successful regulations we have the Netherlands, one of the first countries in the West to allow the marketing and consumption of food products containing insects, we also have the European Union in 2018 approved the import and export of insects for food purposes and in 2021 took a major step, called the regulatory framework, in which the European Food Safety Agency (EFSA) granted preliminary approval for the human consumption of dry beetle larva (Tenebrio based on the regulation of new foods and new food ingredients adopted in 2018 [17].

In Brazil, the consumption of some insects is present in some traditional dishes. One of the most common dishes is the farofa with tana Jura ant (içá), which is much appreciated in the northeastern region. In addition to the içás ants, beetle larvae (Pachymerus nucleorum) are consumed by the residents of rural Minas Gerais, and saúva (Attacephalotes), 5 found in the region [13].

Although there is the consumption of these insects in Brazil appreciated by a minority, as mentioned in the work, on the other hand there is a weight in the cultural issue that instigates and cau- ses a great rejection of entomofagia in the vast majority, another factor that makes dissemination impossible is the absence of legislation that regulates this type of food production, that because it does not exist, it makes the formal marketing of insects prohibited for human consumption. In Brazil, the agencies responsible for this sector are the Ministry of Agriculture and the National Health Surveillance Agency (ANVISA). There is still no regulation in the country that allows the marketing of insects for human consumption, just as there is no prohibition on sale; Most producers of insects for human consumption work in an artisanal and informal manner [17].

The only aspect regulated by the National Health Surveillance Agency (ANVISA) is The Collegiate Board Resolution (RDC) No. 14 of 2014, in which it establishes tolerable limits of "foreign matter" in food. This document lists insects that are considered part of the food production process (food and beverages) and, within established limits, do not threaten human health. That is, the fragment of insects can only be considered failures in the production process, involving from the harvest of food to the final product, packed [34].

\section{Consumer acceptance to edible insects}

Historically, the introduction of new technologies for the production of food or new food items in the human diet have always generated fears on the part of consumers, where the acceptance of food is directly related to the intention of consuming a given product [19]. When arguing about the benefits of human entomofagia, repudiation/disgust about the idea of eating insects is still one of the great barriers. However, given the growing demand for food, these ideas can change rapidly, especially with the globalization and popularization of science and information [35].

Although the human being can survive with different diets, there are psychological factors that make him have specific eating habits, leaving out foods he could consume [19]. As is the case of entomofagia, consumer acceptance was identified as one of the greatest barriers to validation of edible insects as an alternative resource. Since pioneering research, asco to edible insects has been the first and main factor used to explain the negative view of entomofagia by Western culture [16,36].

Recently, scientific studies that sought to evaluate consumer acceptance of edible insects in the West showed a significant change in consumer perception of entomofagia $[37,38,18]$. 
Recognizing the possibility of repulsion to the consumption of insects in its entirety, one of the alternatives highlighted would be the use of insects as ingredients in processed foods, without changing the traditional appearance of the product. This strategy of hiding the insect in food is a more attractive way and that can accelerate its popularization [39].

Studies on consumer acceptance are still fragmented. However, information is the key element for the awareness of the population about the practice of entomofagia [40]. Germany is an example of a country without a real tradition of entomofagia and that currently sells insect-based products, such as hamburgers that take $45 \%$ of a protein mixture made from soy and beetle larvae (Alphitobius diaperinus) [17].

\section{Conclusions}

The use of insects in human food is an alternative to several environmental problems arising from population growth. The use of insect as food brings nutritional benefits and has economic advantages to its production. Despite this, entomofagia is still little accepted for cultural issues and the lack of public policies to demystify this very common practice in the Western world. There is still no legislation, supervision and formal guidance of regulations dealing with the creation, manipulation and consumption of insects in Brazil.

\section{Acknowledgment}

We thank CNPq, UFPB and CAVN that made available resources in the form of scholarships for this research.

\section{Bibliography}

1. Tilman D., et al. "Global food demand and the sustainable intensification of agriculture". Proceedings of the National Academy of Sciences 108.50 (2011): 20260-20264.

2. Msangi S and Rosegrant MW. "Feeding the future's changing diets: Implications for agriculture markets, nutrition, and policy". Edited by Shenggen Fan and Rajul Pandya-Lorch, 65. Washington D. C.: International Food Policy Research Institute (IFPRI) (2012).

3. Henchion M., et al. "Future protein supply and demand: strategies and factors influencing a sustainable equilibrium". Foods 6.7 (2017): 53.
4. Huis A., et al. "Edible insects: future prospects for food and feed security”. FAO ForestryPaper 171. Rome, Italy: FAO (2013).

5. FAO. "Fao Brasil representative presents a scenario of demand for food. Brasilia” (2017).

6. FAOSTAT. Number of people who are undernourished, 2000 to 2016. Our World in Data, (2018).

7. Govorushko S. "Global status of insects as food and feed source: A review". Trends in Food Science and Technology 91 (2019): 436-445.

8. Matos FM., et al. "Enzymatic hydrolysis of black cricket (Gryllus assimilis) proteins positively affects their antioxidant properties". Journal of Food Science 86.2 (2021): 571-578.

9. Vieira CF. "Insects in food: demystifying and recreating conceptions in school". Course Completion Work (Degree in Biological Sciences) - Federal Technological University of Paraná (2016).

10. FAO, Food and agriculture organization of the unites nations. Edible Insects: a solution for food and feed security (2013).

11. Tan HSG., et al. "Tasty but nasty? Exploring the role of sensoryliking and food appropriateness in the willingness to eat unusual novel foods like insects". Food Quality and Preference 48 (2016): 293-302.

12. Imathiu S. "Benefits and food safety concerns associated with consumption of edible insects". NFS Journal 18 (2019): 1-11.

13. Romeiro ET., et al. "Insects as a food alternative: Review article". Food Contexts - Behavior, Culture and Society Magazine 4.1 (2015).

14. Monteiro S., et al. "Insetos - Food for the future". Food and Economic Safety Authority: Risks and Food - Food of the Future, ed 19 (2020): 17-22.

15. Rivera J and Carbonell F. "The edible insects of Peru: Biodiversity and perspectives of entomophagy in the Peruvian context". Science and Development 27 (2020): 5-36.

16. Huis A., et al. "Edible insects: future prospects for food and feed security". FAO Forestry Papers (2013): 171.

17. Tunes S. "Edible Insects". Pesquisa Fapesp Magazine 290 (2020): 60-67.

18. Huis A. "Insects as food and feed, a new emerging agricultural sector: A review". Journal of Insects as Food and Feed 6.1 (2019): 27-44. 
19. Ruiz SN. "Evaluation of the acceptance of food with insects by consumers in São Paulo". Dissertation (Master's in Administration in International Management) - Escola Superior de Propaganda e Marketing, São Paulo (2017).

20. Veldkamp TG., et al. "Insects as a sustainable feed ingredient in pig and poultry diets: a feasibility study". Wageningen UR Livestock Research (2012): 1570-8616.

21. Vilella LM. "Production of insects for use in animal feed". Course Completion Work (Animal Science) - Federal University of Rio Grande do Sul, Porto Alegre 69 (2018).

22. Oonincx DGAB and De Boer IJM. "Environmental Impact of the Production of Mealworms as a Protein Source for Humans - A Life Cycle Assessment". PLoS ONE 7 (2012): 12.

23. Lucas AJS., et al. "Effects of the different process conditions in the evaluation of enzymatic hydrolysis in cinera cheap (Nauphoeta cinerea)". Brazilian Journal of Development, Curitiba 6.7 (2020): 48885- 48898.

24. Ramos-Elorduy J and Moreno JMP. "Alcance y significado del valor nutri de insectos comestibles do Mexico". In: NETO COAST, E.M. (org.). Anthropoenthophagia: Insects in human food. Feira de Santana. UEFS publisher (2011): 77-92.

25. Fasolin LH., et al. "Emergent food proteins - Towards sustainability, health and innovation". Food Research International 125 (2019): 108-586.

26. Imathiu S. "Benefits and food safety concerns associated with consumption of edible insects". NFS Journal 18 (2020): 1-11.

27. Payne CLR., et al. "A systematic review of nutrient composition data available for twelve commercially available edible insects, and comparison with reference values". Trends in Food Science and Technology 47 (2016): 69-77.

28. Soares BS. "The use of edible insects as an alternative source for human food". 2019. $61 \mathrm{f}$. Monograph (Specialization) - Biological Sciences Course, State University Center of the West Zone, Rio de Janeiro (2019).

29. Ribeiro JCR. "Study of the potential of edible insects for application in the food industry". Master's thesis in biochemistry - Abel Salazar Institute of Biomedical Sciences, University of Porto (2017).

30. Nyberg M., et al. "Reasons for eating insects? Responses and reflections among Swedish consumers". International Journal of Gastronomy and Food Science 22 (2020): 100268.
31. Costa Neto EM. "Etnoentomology in the village of Pedra Branca, municipality of Santa terezinha, Bahia". A case study of human interactions/insects. 2003. 199 f. Thesis (Doctorate) - UFSCar, São Carlos (2003).

32. Schickler G. "Nutrinsecta: trajectory and goals. In: NETO COAST, E.M. (org.). Anthropoenthophagia: insects in human food". Feira de Santana: UEFS Editora (2011): 93-102.

33. Maheu E. "Omnivores? Limitations and possibilities of edible and palatable before cultural boundaries: the case of insects". In: NETO COAST, E.M. (org.). Anthropoenthophagia: insects in human food. Feira de Santana: UEFS Editora (2011): 39-54

34. Moraes B and Fernandes L. "The promising edible insect market" (2018).

35. Gullan PJ., et al. "Insects: a summary of entomology. 4. Ed". São Paulo: Roca (2012).

36. Mancini S., et al. "European consumers' readiness to adopt insects as food. A Review". Food Research International 122 (2019): 661-678.

37. Verbeke W. "Profiling consumers who are ready to adopt insects as a meat substitute in a western society". Food Quality and Preference 39 (2015): 147-155.

38. Gmuer A., et al. "Effects of the degree of processing of insect ingredients in snacks on expected emotional experiences and willingness to eat". Food Quality and Preference 54 (2016): 117-127.

39. Cheung LT and Moraes MS. "Innovation in the food sector: insects for human consumption". Interactions, Campo Grande, MS 17.3 (2016): 503-515.

40. Lammers P., et al. "Acceptance of insects as food in Germany is it about sensation seeking, sustainability consciousness, or food disgust". Food Quality and Preference 77 (2019): 78-88.

\section{Assets from publication with us}

- Prompt Acknowledgement after receiving the article

- Thorough Double blinded peer review

- Rapid Publication

- Issue of Publication Certificate

- High visibility of your Published work

Website: www.actascientific.com/

Submit Article: www.actascientific.com/submission.php

Email us: editor@actascientific.com

Contact us: +919182824667 